\title{
FURTHER STUDIES OF MITOCHONDRIAL GENOME VARIABILITY IN PONTO-CASPIAN PROTERORHINUS SPECIES (ACTINOPTERYGII: PERCIFORMES: GOBIIDAE) AND THEIR TAXONOMIC IMPLICATIONS
}

\author{
Pavel A. SOROKIN ${ }^{1}$, Dmitry A. MEDVEDEV ${ }^{1}$, Victor P. VASIL'EV ${ }^{1}$, \\ Ekaterina D. VASIL'EVA ${ }^{2 *}$ \\ ${ }^{1}$ Severtsov Institute of Ecology and Evolution, Russian Academy of Sciences, Russia \\ ${ }^{2}$ Zoological Museum, Moscow State University, Russia
}

\begin{abstract}
Sorokin P.A., Medvedev D.A., Vasil'ev V.P., Vasil'eva E.D. 2011. Further studies of mitochondrial genome variability in Ponto-Caspian Proterorhinus species (Actinopterygii: Perciformes: Gobiidae) and their taxonomic implications. Acta Ichthyol. Piscat. 41 (2): 95-104.
\end{abstract}

Background. A new taxonomy of tubenose gobies of the genus Proterorhinus has been proposed recently. However, some of taxonomic hypotheses have not been confirmed by recent genetic studies or seem not to correspond with ecological features and genetic differentiation of these fishes. The aim of this paper was to test the new taxonomy through a phylogeographic analysis of the fish from 15 sites in Southern Ukraine and Russia, through analyzing the genotypes deposited in the GenBank and to define the range of those species.

Materials and methods. Fin clips were sampled from 52 specimens of tubenose gobies collected from 2003 up to 2009 in 15 localities of the Ponto-Caspian basin. Genomic DNA for amplification of mitochondrial $c y t b$ gene fragment (about $408 \mathrm{bp}$ ) was extracted using the Diatom ${ }^{\circledR D N A}$ Prep 100. The haplotype MedianJoining Network was constructed using the Network 4.5.1.0. software.

Results. Tubenose gobies from the Black Sea basin are represented by two euryhaline species historically distributed in different areas: P. semilunaris in the north-western part of the Black Sea basin (and possibly eastern Aegean basin) and P. marmoratus in the north-eastern part. The hypothesis about freshwater and marine Black Sea Proterorhinus species seems to be not probable. The validity of endemic Crimean P. tataricus is not confirmed, several independent findings presume it to be conspecific with $P$. marmoratus. Some Crimean rivers and reservoirs are populated by $P$. semilunaris which could spread from the Dnieper River basin through the SeveroKrymskyi channel or may be accidentally introduced. The populations from the Caspian Sea and Sea of Azov basins represent the distinct evolutionary lineage of tubenose goby. But their taxonomic state should be analyzed by further molecular genetic studies of a wide scope of Caspian samples.

Conclusion. The present data on the variability of the mitochondrial cyt $b$ gene fragment in different tubenose goby populations result in revision of some previous taxonomic hypotheses in this fish group. At the same time further molecular genetic researches of Caspian populations seem to be the main tool for future development of taxonomic conclusions.

Keywords: tubenose goby, cytochrome $b$ gene, phylogeography, taxonomy, species distribution

\section{INTRODUCTION}

The genus Proterorhinus Smitt, 1899 has been considered a monotypic taxon (Miller 2004) until Stepien et al. (2005) and Stepien and Tumeo (2006) found marked genetic divergence between "freshwater" and "marine" specimens of $P$. marmoratus (Pallas, 1814) with mitochondrial cytochrome $b$ sequence data, concluding that they comprise separate species, namely "marine" P. marmoratus sensu stricto in the Black Sea basin, and "freshwater" P. semilunaris (Heckel, 1837) in both the Black Sea basin and North America (acclimatized populations). Soon Freyhof and Naseka (2007) described a new fresh- water species, P. tataricus Freyhof et Naseka, 2007, from the Chornaya River in the Crimean Peninsula at Sevastopol using morphological features only. They also concluded that "marine" specimens from the Caspian Sea basin likely represented another separate species, namely P. nasalis (Filippi, 1863). These studies resulted in a new taxonomic conception of Proterorhinus as polytypic taxon including at least four species:

- P. semilunaris is distributed in the western part of the Black Sea basin and eastern Aegean basin, entered in water bodies of the North Sea basin and arrived in North America in ballast of ships in 1991;

\footnotetext{
* Correspondence: Dr. Ekaterina D. Vasil'eva, Zoological Museum, Moscow State University, Bol'shaya Nikitskaya 6, Moscow, 125009 Russia, phone: +7 495 6294906, fax:+7 495 6294825, e-mail: vas_katerina@mail.ru
} 
- P. marmoratus inhabits brackish waters in Sevastopol, Crimea and never enters pure freshwaters;

- P. tataricus is freshwater species endemic for the Chornaya River in Crimea;

- P. nasalis is distributed in Azov and Caspian Sea basins and most likely in western Caucasus coast in Russia and Georgia (Kottelat and Freyhof 2007).

The key presented for their identification (Kottelat and Freyhof 2007) was based on a few morphometric characters demonstrating significant overlapping between populations of aforementioned species (number of anal fin rays and number of total scales in midlateral series) and simultaneously subjected to the prominent size-age-related variability in Proterorhinus populations: head length, eye diameter, and interorbital distance (Smirnov 1986). That is why further genetic studies of tubenose goby populations occurred both in marine and fresh waters from different sea basins seemed necessary to define actual structure of the genus (Vasil'eva 2007).

The first step in this direction was made by Neilson and Stepien (2009) in their phylogeographic study of tubenose gobies from 18 "freshwater and marine" localities from the Black and Caspian Sea basins and North America by mitochondrial (cytochrome $b$ and cytochrome $c$ oxidase subunit I) and nuclear (RAG1) DNA sequence analysis, as well as multivariate morphological comparison of both genetically studied and museum materials. Based on their results the present authors assert:

marked genetic and morphological divergence and species-level separation between "freshwater" and marine/brackish (=P. marmoratus) lineages, dating back approximately $3.82-4.30$ million years;

significant genetic and morphological differentiation of freshwater lineages from the Black Sea (=P. semilunaris) and Caspian Sea ("may correspond with P. semipellucidus" (Kessler, 1877)) basins, corresponding to an estimated 0.92-1.03 million years, and they also presume the existence of the fourth lineage within the Kumo-Manych Depression (Proterorhinus sp.) as well as

the probability that "marine" Caspian tubenose gobies represent separate species $P$. nasalis different from freshwater species cf. P. semipellucidus. Moreover their morphological data demonstrate that "key characters" presented by Kottelat and Freyhof (2007) have very low diagnostic values even within not very large amount of studied materials.

The aims of this study were to test the recently proposed taxonomy of the genus Proterorhinus and to define the range of the species by phylogeographic analysis of the tubenose gobies from 15 localities attributed to different sea basins, and particular samples from the Sea of Azov basin and the Chornaya River in the Crimean Peninsula, as well as genotypes previously deposited in the GenBank database.

\section{MATERIAL AND METHODS}

Sampling. Specimens of tubenose goby were collected from 2003 to 2009 at 15 localities (Fig. 1, Table 1).
Anaesthetized fish or their pectoral fins were preserved immediately in $96 \%$ ethanol for molecular studies. Later, pectoral fins from large specimens were separated for molecular studies, whereas fishes were transformed to pure water and then to $75 \%$ ethanol for further including in the ichthyologic collection of the Zoological Museum of the Moscow State University (ZMMU), whereas small specimens were retained in $96 \%$ ethanol for further molecular studies only. Anaesthetized fish with preliminary extracted pectoral fins were preserved in $4 \%$ formaldehyde solution since they were intended for ichthyological collection and further morphological studies. Thus, most DNA analyzed materials belong to voucher specimens kept in ZMMU; their numbers in museum collection are presented in Table 1. Two individuals of round goby, Neogobius melanostomus (Pallas, 1814), from the Black Sea at the Chornaya River mouth, Sevastopol, were sequenced and used as outgroup.

Molecular analysis. Molecular genetic analysis was carried out using the mitochondrial cyt $b$ gene fragment. DNA was extracted from the tissues, fixed either in $96 \%$ ethanol, using the Diatom ${ }^{\circledR D N A}$ Prep 100 (Izogen, Moscow) extraction kit. Gene amplification products were obtained with the help of PCR with primers specific for the cyt $b$ gene with Glu-(L14724) TGATAT-GAAAAACCATCGTTG and Cb2-(H15174)-CCCTCA-GAATGATATTTGTCCTCA (Kocher et al. 1989) primers and using the reagent kit (Dialat, Moscow). The results of amplification were analysed by electrophoresis in $1.5 \%$ agarose gel in TBE buffer with addition of ethidium bromide. Sequencing was performed using an ABI 3130 (Applied Biosystems, USA) sequencer. Sequence alignment of the cyt $b$ (about $408 \mathrm{bp}$ ) gene fragments obtained was performed using the BioEdit 7 software program (Hall 1999). $F_{\text {st }}$ and $P$ value, as well as $\pi$ and $H$ values were computed in ARLEQUIN 3.5 (Excoffier et al. 2005) software programs. The gamma distribution coefficient $\alpha(0,2)$ was computed by hierarchical likelihood ratio tests in Modeltest 3.7 program (Possada and Crandall 2001). The best fit model chosen was HKY $+\mathrm{G}$ (Hasegawa et al. 1985). Maximum likelihood (ML) tree was constructed in PhyML 2.4.4 program (Guindon and Gascuel 2003), and Bayesian tree-in MrBayes 3.1.2 program (Ronquist and Huelsenbeck 2003).

To testify non-random geographic grouping of haplotypes and an inference of demographic processes as the case of the geographic associations the haplotype Median Joining Network was constructed using the Network 4.5.1.0. software (Bandelt et al. 1999).

Sequences determined for tubenose gobies in this study were deposited in the GenBank (Table 1), as well as both sequences determined for round goby (n2 - HQ452491 and n3 - HQ452492). In our analyses we also included haplotypes of tubenose gobies deposited in the GenBank by Neilson and Stepien (2009) in spite of several problems with correct identification of their geographic localities caused by discrepancy between mode of sample coding in tables and different figures in their publication. For example, their haplotype EU444608, designated as Pro5 

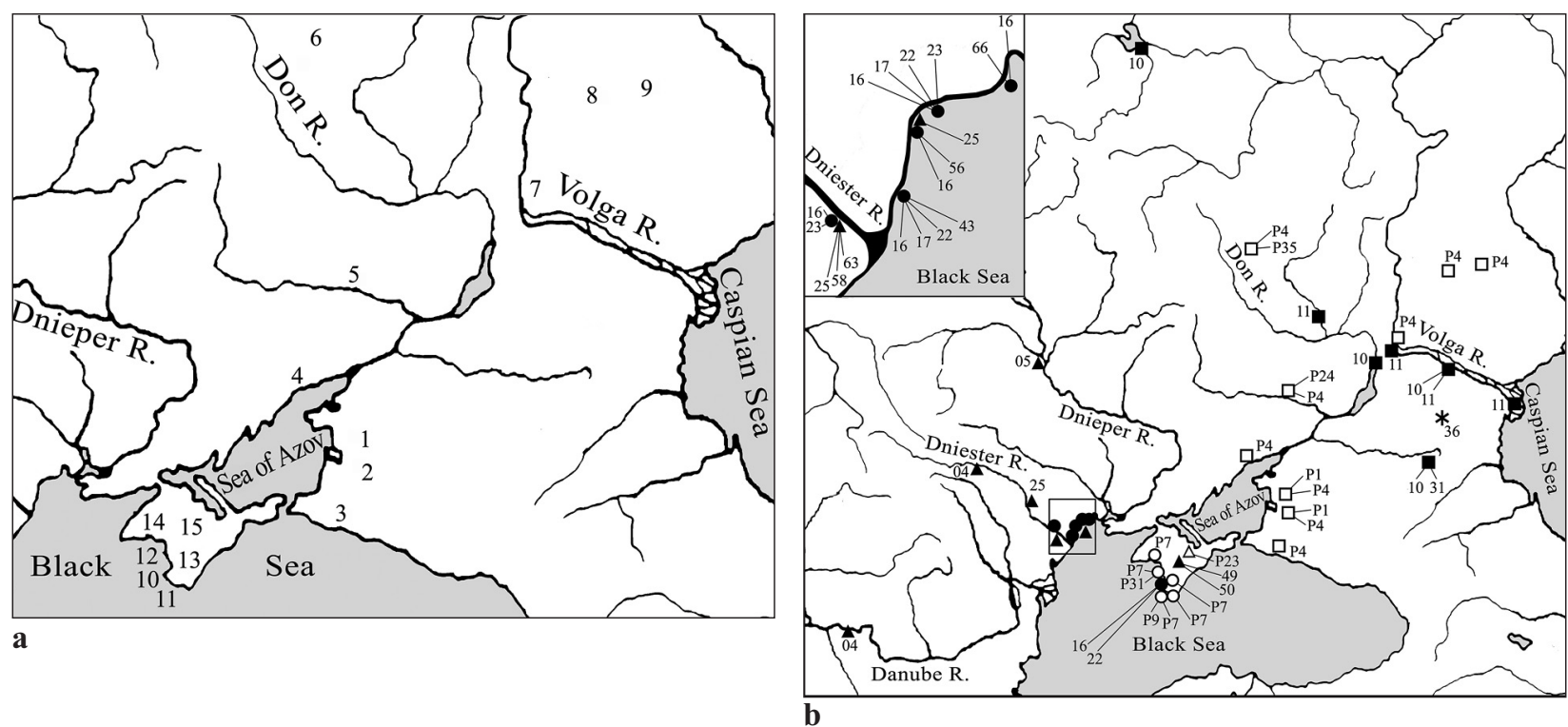

Fig. 1. Map showing (a) the capture locations of 15 studied samples and (b) the distribution of both $\mathrm{mt}$ genotypes revealed in this study (identified by the same numbers as in Table 1) and mt genotypes from the GenBank (identified by last two figures from their numbers presented in Table 2 and marked with black colour): circles represent Proterorhinus marmoratus clade, squares represent Azov-Caspian clade (designated as P. nasalis on Figs. 2 and 3), triangles represent $P$. semilunaris clade and the asterisk represent the only haplotype revealed in the Kumo-Manych Depression presented in the GenBank

Table 1

Sample localities, specimens number $(n)$, numbers in museum collection, designation and number (in brackets) of haplotypes and their GenBank Accession numbers. The localities are numbered according to Fig. 1

\begin{tabular}{|c|c|c|c|c|}
\hline No. & Locality & $n$ & $\begin{array}{c}\text { Museum } \\
\text { number }\end{array}$ & Haplotype \\
\hline 1 & $\begin{array}{l}\text { Zelenchuk R., Krasnodar District, Kuban R. drainage, } \\
\text { Sea of Azov basin }\end{array}$ & 6 & P-21467 & $\begin{array}{l}\mathrm{p} 1=\mathrm{HQ} 452493(3) \\
\mathrm{p} 4=\mathrm{HQ} 452494(3)\end{array}$ \\
\hline 2 & Beisug R., Krasnodar District, Sea of Azov basin & 3 & P-21466 & $\mathrm{p} 1(1), \mathrm{p} 4(2)$ \\
\hline 3 & Abin R., Krasnodar District, Kuban R. drainage, Sea of Azov basin & 6 & P-22059 & $\mathrm{p} 4(6)$ \\
\hline 4 & Mius R., Ukraine, Sea of Azov basin & 2 & $\mathrm{P}-21288$ & $\mathrm{p} 4(2)$ \\
\hline 5 & $\begin{array}{l}\text { Severskyi Donetz R., Rostov District, Don R. drainage, } \\
\text { Sea of Azov basin }\end{array}$ & 4 & - & $\begin{array}{l}\text { p4 (3) } \\
\text { p24 = HQ452498 (1) }\end{array}$ \\
\hline 6 & Matyra R., Tambov District, Don R. drainage, Sea of Azov basin & 4 & P-22206 & $\begin{array}{l}\text { p4 (3) } \\
\text { p35 = HQ452500 (1) }\end{array}$ \\
\hline 7 & Volgograd Reservoir, Volgograd District, Caspian Sea basin & 2 & P-22207 & $\mathrm{p} 4(2)$ \\
\hline 8 & Malyi Uzen' R., Saratov District & 2 & - & $\mathrm{p} 4(2)$ \\
\hline 9 & Bol'shoy Uzen' R., Saratov District & 1 & - & $\mathrm{p} 4$ \\
\hline 10 & Streletskaya Bay, Sevastopol, Black Sea & 3 & P-22153 & $\begin{array}{l}\mathrm{p} 7=\mathrm{HQ} 452495(2) \\
\mathrm{p} 9=\mathrm{HQ} 452496(1)\end{array}$ \\
\hline 11 & Kazachya Bay, Sevastopol, Black Sea & 4 & P-22152 & p7 (4) \\
\hline 12 & Black Sea at Chornaya R. mouth, Sevastopol & 10 & P-22155 & $\begin{array}{l}\text { p7 (9), } \\
\text { p31 = HQ452499 (1) }\end{array}$ \\
\hline 13 & Chornaya R. main stream, Crimean Peninsula & 1 & P-21347 & p7 (1) \\
\hline 14 & Donuzlav Lake, Crimean Peninsula & 3 & - & p7 (3) \\
\hline 15 & Salgir R., Crimean Peninsula & 1 & - & p23 = HQ452497 (1) \\
\hline
\end{tabular}

in the figure 4, should be attributed to the only specimen of from the Dniester River (Neilson and Stepien 2009). Thus, $P$. semilunaris from the Clinton River (USA) according to this haplotype, as well as some others with doubtful inforthe tables 3 and 4 ; but in the figure 4 this haplotype is marked mation on their origin were not included in the present by letter "A" and thus should be treated as P. marmoratus study. The haplotypes from GenBank used for different 
analyses and their identification in tables and figures are presented in Table 2 (similar haplotypes have the same identification).

To elucidate the association of phylogenetic relations among tubenose gobies with geographic locations five population groups were analyzed:

1) from the north-western part of the Black Sea (to the west from the Crimean Peninsula);

2) populations from the Caspian Sea basin;

3) population from the Chernozemel'sky collector represented by a single specimen with haplotype from GenBank;

4) populations from the eastern-north part of the Black Sea;

5) populations from the Sea of Azov basin (see Tables 3-5). These groups included both haplotypes revealed in this study and aforementioned haplotypes from GenBank.

\section{RESULTS}

mtDNA genotypes. A total of 45 cytochrome $b$ gene sequences (408 bp) (GenBank accession Nos. HQ452493-HQ452500) were obtained for Proterorhinus populations. Additionally, two sequences of the fragment cytochrome $b$ gene (408 bp) (GenBank accession Nos. HQ45249-HQ452492) were obtained for Neogobius melanostomus. For the cytochrome $b$ Proterorhinus gene fragment, a total of 8 haplotypes were described, and two haplotypes were described for the out-group represented by Neogobius melanostomus. Table 3 presents nucleotide variation $\pi$ and haplotype diversity index $H$ for different geographic groups of Proterorhinus, whereas $F_{s t}$ and $P$ values are represented in Table 4.
Phylogenetic analysis. Both the maximum likelihood and Bayesian analyses of Proterorhinus cyt $b$ haplotypes demonstrate enough similar topologies of their trees demonstrating two main clades with high bootstrap support for each of them (Figs. 2, 3). The first clade combines haplotypes from different localities in the Black Sea off Sevastopol and from Donuzlav Lake, including haplotypes from the Chornaya River, both from its delta and the main stream, as well as the group of haplotypes from the GenBank identified by Neilson and Stepien (2009) as "marine" P. marmoratus: from Odessa Bay, Sukhoy and Tyligul Estuaries, Dniester delta, and Black Sea off Sevastopol (Fig. 1). The second clade includes two subclades more clear separated by the maximum likelihood analysis (Fig. 3). The first of these clades combines haplotypes from different localities in the Sea of Azov basin, from the Don and Kuban rivers drainages, and Volgograd Reservoir (Volga River basin) as well as haplotypes from the GenBank identified by Neilson and Stepien (2009) as "freshwater" Proterorhinus cf. semipellucidus (Buzuluk R., Volgograd and Rybinsk Reservoirs, Volga R., and Chograiskoye Reservoir). The second subclade combines the haplotype from the only specimen from the Chernozemel'sky channel and the group of haplotypes including the haplotype from the Salgir River (Crimean Peninsula) and haplotypes from the GenBank identified by Neilson and Stepien (2009) as "freshwater" P. semilunaris (Simferopol Reservoir, Dniester and Dnieper rivers, Kuchurgansky Reservoir, Odessa Bay and North American acclimatizers).

Table 2

The haplotypes of Proterorhinus specimens from the GenBank used in the study and their designation in Figs. 1-4

\begin{tabular}{lc}
\hline GenBank accession number & Designation \\
\hline EU444604, EU444612 & 04 \\
EU444605, EU444607 & 05 \\
EU444606 & 06 \\
EU444610, EU444630 & 10 \\
EU444611 & 11 \\
EU444616, EU444620, EU444621, EU444624, EU444637, EU444647, EU444655 & 16 \\
EU444617 & 17 \\
EU444622, EU444653, EU444638 & 22 \\
EU444623 & 23 \\
EU444625, EU444626, EU444632, EU444660, EU444661 & 25 \\
EU444631 & 31 \\
EU444636 & 36 \\
EU444643 & 43 \\
EU444649 & 49 \\
EU444650 & 50 \\
EU444656 & 56 \\
EU444658 & 56 \\
EU444663 & 58 \\
EU444666 & 53
\end{tabular}


Table 3

Haplotype $(\mathrm{H})$ and nucleotide $(\pi)$ diversity values (mean value and SD) in different (1-5) geographic population groups of Proterorhinus designated as in the Material and methods

\begin{tabular}{lcccc}
\hline Estimate & 1 & 2 & 4 & 5 \\
\hline $\mathrm{H}$ & $0.91 \pm 0.04$ & $0.67 \pm 0.16$ & $0.56 \pm 0.13$ & $0.40 \pm 0.11$ \\
$\pi$ & $0.072 \pm 0.036$ & $0.021 \pm 0.002$ & $0.035 \pm 0.018$ & $0.001 \pm 0.001$ \\
\hline
\end{tabular}

Population pairwise $F_{s t}$ and $P$ value estimates for different geographic population groups of Proterorhinus designated as in the Material and methods and N. melanostomus (6) obtained by using data from the mitochondrial cyt $b$

\begin{tabular}{lllllll}
\hline Group & \multicolumn{1}{c}{1} & \multicolumn{1}{c}{2} & 3 & 4 & 5 & 6 \\
\hline 1 & 0 & & & & & \\
2 & $0.385^{*}$ & 0 & & & & \\
3 & 0.103 & 0.934 & 0 & & & \\
4 & $0.179 *$ & $0.737 *$ & 0.668 & 0 & & \\
5 & $0.543^{*}$ & $0.204^{*}$ & $0.959 *$ & $0.828^{*}$ & 0 & \\
6 & $0.660^{*}$ & $0.988^{*}$ & 0.987 & $0.816^{*}$ & $0.992^{*}$ & 0 \\
\hline
\end{tabular}

$F_{s t}$ values were significant (*) with $P<0.05$.

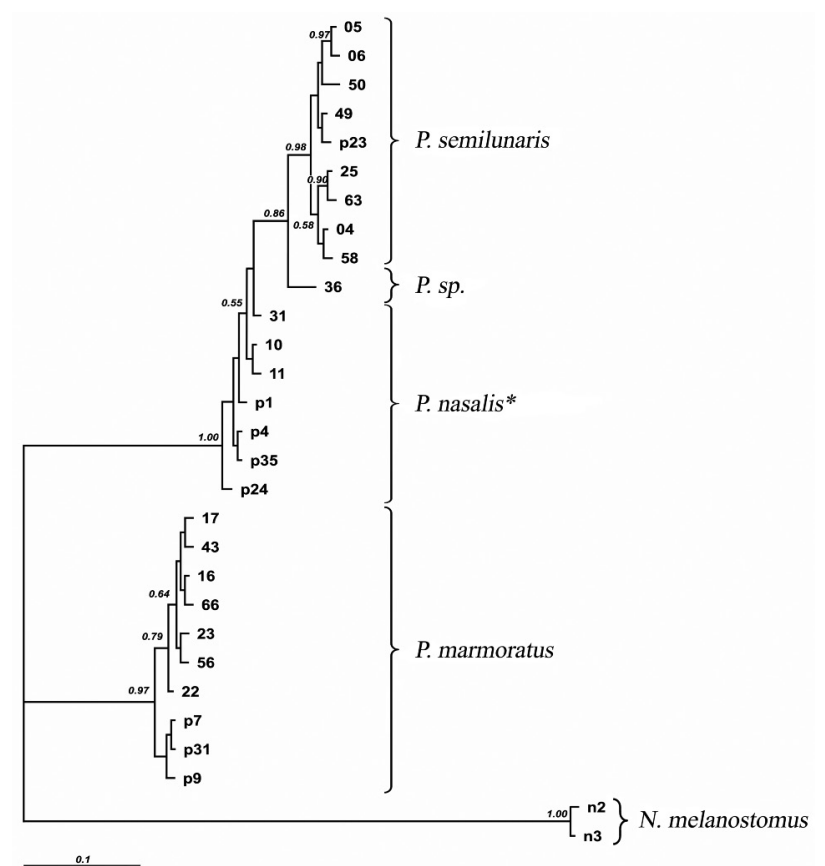

Fig. 2. Bayesian consensus tree resulting from the analysis of Proterorhinus cytochrome $b(408 \mathrm{bp}$ ) haplotypes identified by the same numbers as in Tables 1 and 2 and Fig. 1. Neogobius melanostomus samples (n) are taken as out-group; Numbers near branches indicate maximum likelihood bootstrap values (only values $P>0.5$ are shown) followed by Bayesian posterior probabilities; $(*)$ The identification of this subclade as $P$. nasalis is preliminary and needs further studies (see the text)

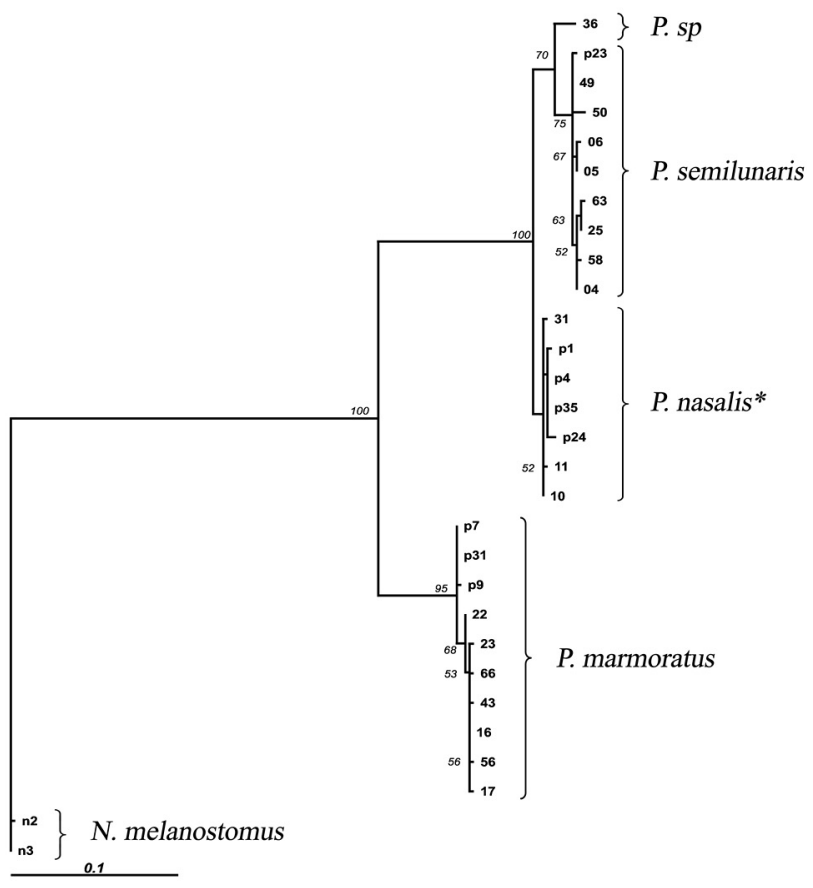

Fig. 3. Maximum likelihood analysis of Proterorhinus cytochrome $b$ (408 bp) haplotypes identified by the same numbers as in Tables 1 and 2 and Fig. 1. Neogobius melanostomus samples (n) are taken as outgroup; Numbers near branches (only values $P>50$ are shown) indicate maximum likelihood bootstrap support (1000 pseudoreplications); (*) The identification of this subclade as $P$. nasalis is preliminary and needs further studies (see the text)

Haplotype network is consistent with tree-based lineages delimitation (Fig. 4). Main tubenose goby haplotype groups are well associated with geographic location, except several haplotypes including in geographically distant group, namely haplotypes from the Salgir River and Simferopol Reservoir among the haplotypes of the northwestern Black Sea group and several haplotypes from the north-western Black Sea populations gathering with the haplotype group from the Black Sea at Sevastopol. It should be marked that the last haplotype group is the most diverged from the others. And the group of haplotypes from the Caspian Sea and Sea of Azov basin is defined as intermediate group more related with the northwestern Black Sea haplotypes.

The analysis of geographically separated population groups demonstrates the highest both nucleotide and haplotype diversities among tubenose populations distributed in the north-western part of the Black Sea (Table 3). The populations occurred in the Sea of Azov basin exhibits extremely reduced levels of diversity, whereas tubenose gobies from the Caspian Sea basin are characterized by significantly higher haplotype diversity, but low nucleotide diversity. Both the Caspian and Azov population groups possess close related haplotypes with low numbers of nucleotide rearrangements caused by transitions, substitutions and transversions (Table 5) that is consistent with their close grouping together by haplotype 


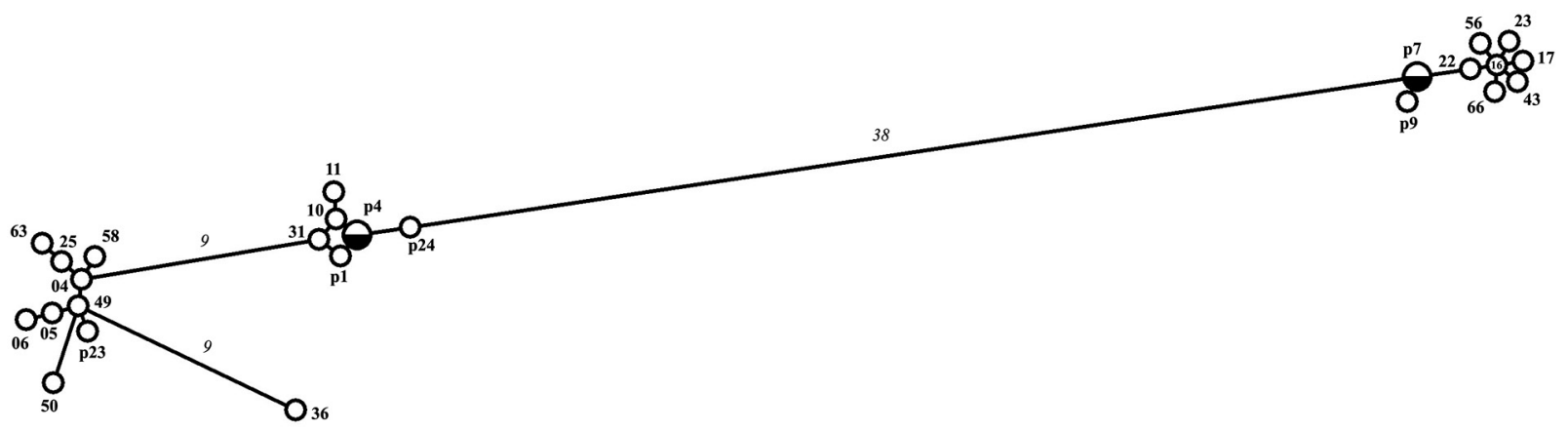

Fig. 4. Haplotype Median Joining Network for the Proterorhinus samples based on the cyt b gene fragment (408 bp) data; A haplotype is represented by a circle; Each haplotype is identified by the same number as in Tables 1 and 2 and Figs. 1, 2, and 3; each line length is related with the number of evolution steps presented at the line; Haplotypes p4 and p35 join in p4, p7 and p31 join in p7 in this analysis

Table 5

Molecular diversity indexes for different geographic population groups of Proterorhinus designated as in Table 4

\begin{tabular}{lccccc} 
Index & 1 & 2 & 4 & 5 & 6 \\
\hline No. of transitions & 44 & 1 & 42 & 3 & 0 \\
No. of transversions & 12 & 1 & 13 & 1 & 1 \\
No. of substitutions & 56 & 2 & 55 & 4 & 1 \\
No. of transition sites & 43 & 1 & 42 & 3 & 0 \\
No. of transversion sites & 12 & 1 & 13 & 1 & 1 \\
No. of substitution sites & 54 & 2 & 53 & 4 & 1 \\
\hline
\end{tabular}

network analysis and the absence of high diverged unique haplotypes (Fig. 4). The statistical significance of population differentiation tested by $F_{s t}$ for all geographic population groups are high and testify to significant $(P<0.05)$ genetic isolation between them, except the tubenose goby from Chernozemel'sky channel demonstrating insignificant differences from most of other groups (Table 4).

\section{DISCUSSION}

As a whole, our results are similar to ones obtained by Neilson and Stepien (2009) and testified to taxonomic diversity of tubenose gobies. But the expanding of areas of molecular genetic investigations, as well as the including of general biological approaches in data analysis allows us to revise some previous hypotheses about taxonomy, zoogeography and evolution of tubenose gobies and to try to answer some important questions presented below.

1. Are there true marine and freshwater tubenose goby species in the Black Sea basin? Indeed, haplotypes from different localities within the Black Sea basin form two separate lineages with high level of genetic divergence (Neilson and Stepien 2009; this study). But careful analysis of these lineages demonstrates that they cannot be classified as true "marine" and "freshwater" Black Sea lineages. Exactly, gobies with haplotypes from "freshwater" clade sensu Neilson and Stepien comprise $22.7 \%$ of fishes collected in the Odessa Bay with water salinity 14-17 ppt. On the contrary, in the Dniester River delta with salinity $0-2$ ppt there were $33.3 \%$ of gobies with
Table 6

The numbers of "freshwater" and "marine" haplotypes, their GenBank accession numbers (designated as in Table 2, in brackets) (before slash) and specimens with these haplotypes (after slash) in different localities with salinity (parts per thousand) according to the data from Nielsen and Stepien (2009)

\begin{tabular}{lccc}
\hline Locality & $\begin{array}{c}\text { Salinity } \\
\text { (ppt) }\end{array}$ & $\begin{array}{c}\text { "Freshwater" } \\
\text { haplotypes }\end{array}$ & $\begin{array}{c}\text { "Marine" } \\
\text { haplotypes }\end{array}$ \\
\hline Dniester R. delta & $0-2$ & $9(25,58-65) / 10$ & $3(21,23,24) / 5$ \\
Odessa Bay & $14-17$ & $4(25-28) / 5$ & $\begin{array}{c}12(17,21,23,24, \\
35,45,52-57) / 17\end{array}$ \\
\hline
\end{tabular}

"marine" haplotypes (Table 6, calculated by the data from Neilson and Stepien 2009). Sympatric distribution of these haplotype lineages in aforementioned localities are presented in Fig. 1. Moreover, all of 15 specimens collected in the Tyligul Estuary with salinity 4 ppt had "marine" haplotypes (Neilson and Stepien 2009), and the specimen caught in fresh water of the Chornaya River possessed the haplotype (p7) clustered together with "marine" haplotypes (this study). According to these data, both "marine" and "freshwater" Black Sea lineages should be treated as euryhaline species dwelling in waters with salinity varying from 0 ppt in rivers and reservoirs up to $18.2 \mathrm{ppt}$ in Donuzlav Lake and several Black Sea bays (Kuftarkova et al. 2008, Manilo 2009a). It should be also emphasized that specimens from both phylogenetic lineages are commonly found in marine bays and estuaries (Miller 2004, Naseka et al. 2005, Antsulevich 2007, Manilo 2009a, b, our unpublished data), where the salinity changes regularly. For example, the water salinity of the Sevastopol Bay, where we collected numerous samples of tubenose gobies ("marine" clade according this study) at the Chornaya River mouth in July 2008, varies in different parts, levels and seasons from 9.72 to $18.32 \mathrm{ppt}$ (Ivanov et al. 2006). The salinity of the Odessa Bay, where were collected samples with both "marine" and "freshwater" haplotypes (Neilson and Stepien 2009), varies in different coastal parts in spring (May) from 5.50 up to $14.98 \mathrm{ppt}$ and from 11.20 up to 16.80 ppt in Autumn and Winter (Anonymous 1999, Tučkovenko et al. 2004). 
It should be also mentioned, that the hypothesis about marine and freshwater lineages of tubenose gobies looked initially questionable because of known data on their distribution, ecology, and invasive expansions (Miller et al. 2004, Prášek and Jurajda 2005, Von Landwüst 2006, Karpova 2009, Manilo 2009, Galanin 2009, Semenchenko, 2011). For instance, even recently described "freshwater" $P$. tataricus is recorded both from "brackish estuary of stream Chornaya" and upstream localities from river section "about 25-30 km long" (Freyhof and Naseka 2007, Kottelat and Freyhof 2007). However, the estuary of the Chornaya River is characterized by very high variability of its salinity varying from 2.82 up to $16.17 \mathrm{ppt}$ in superficial layers and from 14.34 up to $17.58 \mathrm{ppt}$ at the bottom (Boltačëv et al. 2010).

Thus, aforementioned hypothesis about freshwater and marine Black Sea Proterorhinus species obviously should be rejected. Instead, two evolution lineages of haplotypes observed among the Black Sea basin samples should be considered as euryhaline separate species historically distributed in different areas, namely $P$. semilunaris in the western part of the Black Sea basin (and possibly eastern Aegean basin) and P. marmoratus in north-eastern part of the Black Sea basin (possibly including Georgia), as it was earlier accepted by Kottelat and Freyhof (2007). In this case the presence of haplotypes from both lineages in the Odessa Bay and the Dniester Delta following from data presented by Neilson and Stepien (2009) and revealed in this study (Fig. 1) should be explained by recent expansion and secondary contact of these species. The previous hypothesis could not explain mixed nature of genetically studied samples from these localities. Whereas a new concept is consistent with high haplotype and nucleotide diversities observed in north-western Black Sea geographic population group (Table 3).

2. Is $\boldsymbol{P}$. tataricus valid species? The haplotype clade from the north-eastern part of the Black Sea corresponding to $P$. marmoratus sensu stricto includes specimens from both estuarine and freshwater parts of the Chornaya River in the Crimean Peninsula. Moreover, tubenose gobies from the Kazachya Bay and Donuzlav Lake possessed the same haplotype (p7) as the specimen from the freshwater part of the Cornaya River, and fishes with this haplotype dominated (Table 1) in the samples from the Streletskaya (66.7\%) and Sevastopol Bay (90\%). Thus, the same haplotype most probably was intrinsic to the holotype of Gobius marmoratus described from Sevastopol. In such a way molecular analysis does not confirm validity of $P$. tataricus described from the Chornaya River after comparative morphometric analysis (Freyhof and Naseka 2007). Despite of required further study on nuclear genome in different populations of tubenose gobies, it should be emphasized that aforementioned morphological analysis has been conducted by using sets of samples later proved to be genetically heterogeneous. Indeed, P. marmoratus sensu Freyhof and Naseka (2007) combines samples from the Sevastopol Bay (and other eastern-north Black Sea localities) geneti- cally identified as P. marmoratus, as well as samples from Bulgaria, Romania, and other western Black Sea localities genetically confirmed as $P$. semilunaris (see Neilson and Stepien 2009, this study). Therefore, it is not surprising, that further preliminary morphological studies reveal high variability of $P$. tataricus key characters in different tubenose goby population and their poor diagnostic value (Karpova 2009, Neilson and Stepien 2009, our unpublished data) also testifying to probable conspecificity of $P$. tataricus and P. marmoratus.

Apart from genetic and morphological evidences tubenose gobies occurred in the Chornaya River certainly belong to typical euryhaline populations of $P$. marmoratus. Freyhof and Naseka (2007) "identified" as P. tataricus at least seven specimens caught in "brackish estuary of stream Chornaya" (p. 328). But as it was mentioned above, this estuary is characterized by considerable horizontal gradients and strong stratification of superficial and benthonic salinity (Boltačëv et al. 2001, Karpova 2009) reaching 18.0-18.1 ppt in several seasons and depth (Ivanov et al. 2006). In any case its water should be characterized as pleiomesohaline-polyhaline zone, not significantly differed from other parts of the Sevastopol Bay (see above) populated by "marine" P. marmoratus. Karpova (2009) reported P. marmoratus from the Chornaya River mouth, we also found a lot of small tubenose gobies in the Chornaya River estuary and neighbouring sea waters in July 2008. Therefore there are no reasons to presume any isolation between tubenose gobies from the Chornaya River and other local populations of P. marmoratus dwelling in the Sevastopol Bay.

Incomplete molecular studies of tubenose goby populations through the whole Proterorhinus area create obstacles to develop a complete evolutionary scenario for this species group. However, the concept of divergence times estimated for different phylogenetic lineages by Neilson and Stepien (2009) presumes that "the first major division within Proterorhinus occurred approximately 4.2-4.4 Mya, separating the marine and freshwater taxa" (p. 678). This estimate undoubtedly refutes any assumption on endemic freshwater Proterorhinus species in the Chornaya River in Crimea. In concordance with major geological events in the Ponto-Caspian basin the freshwater fauna of the Chornaya River is supposed to be isolated from the recent freshwater fauna of the northern coast of the Black Sea basin since the Paleocene period (Puzanov 1949), about 60 Mya. This fauna includes several endemic species, for instance, one species of simuliids, one subterranean amphipod, and two endemic fish species, namely Cobitis taurica Vasil'eva, Vasil'ev, Janko, Ráb et Rábová, 2005 (Cobitidae) and Gobio taurica Vasil'eva, 2005 (Cyprinidae) (Vasil'eva et al. 2005). In this case P. tataricus had to be "older" than "freshwater" group of tubenose goby, but it was not discovered in fresh waters of Crimea (Delâmure 1964) up to the end of 20th century.

3. What tubenose goby species occurs in several Crimean rivers and reservoirs? The evolution lineage of tubenose goby corresponding to species $P$. semilunaris 
includes haplotypes from the north-western part of the Black Sea basin but also haplotypes from so called Steppe Crimea (lowland part of the Crimean Peninsula zoo-geographically differed from the south-eastern Mountain Crimea): the Salgir River and Simferopol Reservoir organized on this river (Neilson and Stepien 2009, this study, Fig. 1). That is why north-eastern Black Sea population group included both coastal and freshwater populations from Crimean Peninsula shows enough high nucleotide and haplotype diversities (Table 3, group 4). However, this phenomenon should not be related with historical distribution of mentioned species, but caused by anthropogenic factors. Certainly, the populations of $P$. semilunaris in freshwaters of Crimea are not native because up to the end of 20th century_Neogobius fluviatilis (Pallas, 1814) was the only goby species revealed there (Delâmure 1964). Consequently, these tubenose gobies could spread from the Dnieper River basin through Severo-Krymskyi channel connected the Dnieper River and Crimean freshwaters and then widely distributed through smaller channels. It should be mentioned that $P$. semilunaris is characterized by rapid colonization of new habitats (Naseka et al. 2005, Prášek and Jurajda 2005, Manné and Poulet 2008). Another possible source of the penetration of north-western gobies in Crimean Peninsula could be an accidental introduction caused by acts on acclimatization of economic-valuable fishes in Crimean reservoirs. As a result, they were found by J. Freyhof (see Freyhof and Naseka 2007) in several Crimean rivers, namely Al'ma and Kacha. The same reasons resulted in an appearance of spined loach Cobitis taenia Linnaeus, 1758 (Cobitidae, Cypriniformes) in the Al'ma River, Crimea. This finding should not be treated as colonization from presumed refugial population (Culling et al. 2006), because historically C. taenia was absent in the Al'ma River.

4. How many tubenose goby species occur in the Caspian Sea and the Sea of Azov basin? The third distinct evolutionary lineage of tubenose goby is represented by populations distributed after realization of irrigation and damming programs in the Sea of Azov basin, the Kuban and Volga River drainages, as well as in isolated rivers (Bol'shoi and Malyi Uzen') of Saratov District of Russian Federation and Kazakhstan and in the Chograiskoye Reservoir in Kalmykiya (Figs. 1-3, Table 1). As a result of recent artificial connections between historically independent river systems and high potentiality for fast expansion characterized for tubenose gobies, it is very problematic to define native or alien origin of some local populations and their Caspian or Azov relationships in spite of significant differences revealed in this study between Caspian and Azov population groups. For example, Chograyskoye Reservoir was created on the Chograi River, tributary of the Vostochnyi Manych River, historically connected through the Kalaus River with the Zapadnyi Manych River (tributary of the Don River) but isolated from the Caspian Sea. Today, the Kalaus River is separated from the Vostochnyi Manych River, and Chograyskoye Reservoir is filled by water from the
Kumo-Manych channel which is filled by the TerekKuma channel. Thus, recent population of tubenose gobies occurred in Chograyskoye Reservoir may have both Caspian and Azov origins. One from two closely related haplotypes revealed by Neilson and Stepien (2009) for this population (EU444610) was also revealed in the Caspian and Azov basins (Fig. 1). The same doubtful state should be presumed for recent populations from the Volga River connected with the Sea of Azov basin through the Volga-Don channel. In this connection two taxonomic hypotheses look probable from molecular analysis:

tubenose gobies from the third genetic lineage belong to valid species $P$. nasalis widely distributed in the Caspian and Sea of Azov basins (in this case P. semipellucidus should by treated as its junior synonym);

the third genetic lineage represents separate species historically distributed in the Sea of Azov basin and further entered the Volga River basin (or historically distributed in the Azov Sea basin and Northern Caspian and possibly correspondent to $P$. semipellucidus), but this species genetically differs from tubenose gobies dwelling in the Caspian Sea basin (or in the Middle and Southern Caspian) and classified as $P$. nasalis sensu stricto.

The second hypothesis is partially similar to aforementioned conception assumed two Caspian species: "truly marine" Caspian P. nasalis and "freshwater" Caspian P. semipellucidus (Neilson and Stepien 2009). But the last assumption failed to take into account ecological peculiarities of tubenose gobies and was based on incomplete genetic information (populations from the Sea of Azov was not studied).

The first hypothesis about the only widespread CaspianAzov Sea tubenose goby species seems enough probable, because specimens from both the Bol'shoi and Malyi Uzen' rivers flowing into isolated lakes of Kazakhstan belong to the same clade with fishes from the Sea of Azov basin and the Volga River (Figs. 2-4). This conception of widely distributed $P$. nasalis is accepted by Kottelat and Freyhof (2007). However, a single specimen from the Chernozemel'skyi channel (the Kumo-Manych Depression) with its significantly diverged haplotype may be considered as possible evidence for the second hypothesis. Indeed, the Chernozemel'skyi channel is connected with Chograyskoye Reservoir. But, as it was mentioned above, its recent ichthyofauna should have Caspian and/or Azov roots. Accordingly, the diverged specimen from the Chernozemel'skyi channel may belong to Caspian P. nasalis sensu stricto different from other genetically studied populations of separate species from the Sea of Azov and Northern Caspian basins. But recent study demonstrates indefinite state of tubenose goby from the Chernozemel'skyi channel. Any solution needs further molecular genetic studies of Caspian tubenose goby populations.

\section{ACKNOWLEDGEMENTS}

The present study was supported in part by the Russian Foundation for Basic Research (grants numbers 10-04-00339, and 09-04-00211), and the Program of 
Presidium of the Russian Academy of Sciences "Dynamics of Gene Pools of Populations". The authors are very thankful to Dr. A.R. Boltačëv [Boltachev] (Institute Biology of Southern Seas, NAS Ukraine, Sevastopol) and Dr. A.N. Reshetnikov (Severtsov Institute of Ecology and Evolution RAN) presented some samples for this study.

\section{REFERENCES}

Anonymous 1999. Êkologičeskie problemy Černogo morâ; sbornik naučnyh statej. [Ecological problems of Black Sea: Collected papers. OCHTÊI [OCSTEI.], Odessa. [In Russian with English summary.]

Antsulevich A. 2007. First records of the tubenose goby Proterorhinus marmoratus (Pallas, 1814) in the Baltic Sea. Aquatic Invasions 2 (4): 468-470. DOI: 10.3391/ai.2007.2.4.23.

Bandelt H.J., Forster P., Röhl A. 1999. Median-joining networks for inferring intraspecific phylogenies. Molecular Biology and Evolution 16 (1): 37-48.

Boltačëv A.R. [Boltachev A.R.], Karpova E.P., [Danilyuk O.N.] 2010. Osobiennosti termohalinnyh parametrov i ihtiocena êstuariâ reki Čërnaâ (Sevastopol'skaâ buhta). [Peculiarities of thermohaline parameters and ichthyocenosis of the Chernaya river estuary (the Sevastopol bay).] Morskoj êkologičeskij žurnal [Morskoj ehkologicheskij zhurnal.] 9 (2): 23-36. [In Russian.]

Culling M.A., Janko K., Boroń A., Vasil'ev V.P., Côté I.M., Hewitt G.M. 2006. European colonization by the spined loach (Cobitis taenia) from Ponto-Caspian refugia based on mitochondrial DNA variation. Molecular Ecology 15 (1): 173-190. DOI: 10.1111/j.1365-294X.2005.02790.x.

Delâmure S.L. [Delyamure S.L.] 1964. Priroda Kryma: Ryby presnyh vodoemov. [Crimean nature: Fishes from the freshwaters.] Izdatel'stvo “Krym”, Simferopol', Ukraine. [In Russian.]

Excoffier L., Laval G., Schneider S. 2005. Arlequin (ver. 3.0): An integrated software package for population genetics data analysis. Evolutionary Bioinformatics Online 1: 47-50.

Freyhof J., Naseka A.M. 2007. Proterorhinus tataricus, a new tubenose goby from Crimea, Ukraine (Teleostei: Gobiidae). Ichthyological Exploration of Freshwaters 18 (4): 325-334.

Galanin I.F. 2009. Issledovaniâ passeleniâ byčka-cucika Proterorhinus marmoratus (Pallas, 1814) v Kujbyševskom vodohranilise. [Studies on tubenose goby Proterorhinus marmoratus (Pallas, 1814) expansion in the Kuibyshev Reservoir.] Učenye zapiski Kazanskogo gosudarstvennogo universiteta; Estestvennye nauki [Uchenye zapiski Kazanskogo gosudarstviennogo universiteta; Estestvennye nauki.] 151 (2): 250-259. [In Russian with English summary.]

Guindon S., Gascuel O. 2003. A simple, fast, and accurate algorithm to estimate large phylogenies by maximum likelihood Systematic Biology 52 (5): 696-704. DOI:10.1080/10635150390235520.

Hall T.A. 1999. BioEdit: A user friendly biological sequence alignment editor and analysis program for Windows 95/98/NT, Nucleic Acids Symposium Series 1999 (41): 95-98.

Hasegawa M., Kishino H., Yano T. 1985. Dating of the human-ape splitting by a molecular clock of mitochondrial DNA. Journal of Molecular Evolution 22 (2): 160-174. DOI: 10.1007/BF02101694.
Ivanov V.A., Ovsânyj E.I. [Ovsyany E.I.], Repetin L.N., Romanov A.S., Ignat'eva O.G. [Ignatyeva O.G.] 2006. Gidrologo-gidrohimičeskij režim Sevastopol'skoj buhty i ego izmieneniâ pod vozdejstvem klimatičeskih i antropogennyh faktorov. [Hydrological and hydrochemical regime of the Sebastopol Bay and its changing under influence of climatic and anthropogenic factors.] Morskoj gidrofizičeskij institut Nacional'noj akademii nauk Ukrainy, Sevastopol, Ukraine. [In Russian with English summary.]

Karpova E.P. 2009. Rasprostranenie ryb semejstva byčkovyh (Gobiidae) v presnyh vodoemah Kryma. [Distribution of fish from family Gobiidae in Crimean fresh waters.] Pp. 59-62. In: Sučasnì problemi teoretičnoï ì praktičnoï ìhtìologii. Tezy II Mižnarodnoï naukovo-praktičnoï konferenciï [Recent problems of theoretical and practical ichthyology. Abstracts of 2nd International theoretical and practical Conference.], 16-19 September 2009, Sevastopol', Ukraine. [In Russian.]

Kocher T.D., Thomas W.K., Meyer A., Edwards S.V., Pääbo S., Villablanca F.X., Wilson A.C. 1989. Dynamics of mitochondrial DNA evolution in animals: Amplification and sequencing with conserved primers. Proceedings of the National Academy of Sciences, USA 86 (16): 6196-6200. DOI:10.1073/pnas.86.16.

Kottelat M., Freyhof J. 2007. Handbook of European freshwater fishes. Kottelat and Freyhof, Cornol, Switzerland, Berlin, Germany.

Kuftarkova E.A., Rodionova N.Û. [Rodionova N.Yu.], Gubanov V.I. [Goubanov V.I.], Bobko N.I. 2008. Gidrohimičeskaâ harakteristika otdel'nyh buht Sevastopol'skogo vzmorâ. [Hydrochemical characteristics of several bays of Sevastopol coast.] Trudy ÛgNIRO [Trudy YugNIRO.] 46: 110-117. [In Russian with English title.]

Manilo L.G. 2009a. Byčkovye ryby (Gobiidae, Perciformes) severo-zapadnoj časti Černogo morâ i prilegaûŝih limannyh êkosistem. [Gobies fishes (Gobiidae, Perciformes) of northwestern part of the Black Sea and adjoining estuary ecosystems.] Zbìrnik prac' Zoologičhogo muzeû 2008-2009 (40): 19-46. [in Russian with English summary.]

Manilo L.G. 2009b. Galopatiâ byčkovyh ryb (Gobiidae) iz severo-zapadnoj časti Černogo morâ. [Halopathy in goby fish (Gobiidae) from the north-western part of the Black Sea.] Pp. 94-98. In: Sučasnì problemi teoretičnoï ì praktičnoï ìhtìologiï. Tezy II Mižnarodnoï naukovo-praktičnoï konferenciï [Recent problems of theoretical and practical ichthyology. Abstracts of 2nd International theoretical and practical Conference.], 16-19 September 2009, Sevastopol', Ukraine. [In Russian.]

Manné S., Poulet N. 2008. First record of the western tubenose goby Proterorhinus semilunaris (Heckel, 1837) in France. Knowledge and Management of Aquatic Ecosystems 2008 (389/03): 03p1-05p5. DOI: 10.1051/kmae:2008009.

Miller P.J. (ed.) 2004. The freshwater fishes of Europe. V. 8/II. Gobiidae 2. AULA-Verlag, Wiebelsheim.

Naseka A.M., Boldyrev V.S., Bogutskaya N.G., Delitsyn V.V. 2005. New data on the historical and expanded range of Proterorhinus marmoratus (Pallas, 1814) (Teleostei: Gobiidae) in Eastern Europe. Journal of Applied Ichthyology 21 (4): 300-305. DOI: 10.1111/j.1439-0426.2005.00685.x. 
Neilson M.E., Stepien C.A. 2009. Evolution and phylogeography of the tubenose goby genus Proterorhinus (Gobiidae: Teleostei): evidence for new cryptic species. Biological Journal of the Linnean Society 96 (3): 664-684. DOI: 10.1111/j.1095-8312.2008.01135.x.

Possada D., Crandall K.A. 2001. Selecting the best-fit model of nucleotide substitution. Systematic Biology 50 (4): 580-601. DOI: 10.1080/10635150118469.

Prášek V., Jurajda P. 2005. Expansion of Proterorhinus marmoratus in the Morava River basin (Czech Republic, Danube R. watershed). Folia Zoologica 54 (1-2 ): 189-192.

Puzanov I.I. 1949. Svoeobrazie fauny Kryma i ee proishoždenie. [The peculiarity of Crimean fauna and its origin.] Učenye zapiski Gor'kovskogo gosudarstvennogo universiteta 1949 (14): 5-32. [In Russian.]

Ronquist F., Huelsenbeck J.P. 2003. MrBAYES 3: Bayesian phylogenetic inference under mixed models. Bioinformatics 19 (12): 1572-1574. DOI: 10.1093/bioinformatics/btg180.

Semenchenko V., Grabowska J., Grabowski M., Rizevsky V., Pluta M. 2011. Non-native fish in Belarusian and Polish areas of the European central invasion corridor. Oceanological and Hydrobiological Studies 40 (1): 57-67. DOI: $10.2478 / \mathrm{s} 13545-011-0007-6$.

Smirnov A.I. 1986. Perciformes (Gobioidei), Scorpaeniformes, Pleuronectiformes, Gobiesociformes, Lophiiformes. Fauna Ukrainy 8. Ryby (5). Naukova Dumka, Kiev. [In Russian.]

Stepien C.A., Brown J.E., Neilson M.E., Tumeo M.A. 2005. Genetic diversity of invasive species in the Great Lakes versus their Eurasian source populations: Insights for risk analysis. Risk Analysis 25 (4): 1043-1060. DOI: 10.1111/j.1539-6924.2005.00655.x.

Stepien C.A., Tumeo M.A. 2006. Invasion genetics of PontoCaspian gobies in the Great Lakes: A 'cryptic' species, absence of founder effects, and comparative risk analysis. Biological Invasions 8 (1): 61-78. DOI: 10.1007/s10530-005-0237-x.

Tučkovenko Û.S. [Tuchkovenko Y.S.], Docenko S.A., Dâtlov S.E. [Dyatlov S.E.], Nesterova D.A., Skripnik I.A., Kirsanova E.V. 2004. Vliânie gidrologičeskih uslovij na izmienčivost' gidrohimičeskih i gidrobiologičeskih harakteristik vod odesskogo regiona severo-zapadnoj časti černogo morâ. [Influence of hydrological conditions on variability of hydrochemical and hydrobiological characteristics of waters in Odessa region in northwestern part of the Black Sea.] Mors'kij êkologičnij žurnal [Morskyji ehkologichnyji zhurnal.] 3 (4): 75-85. [In Russian with English summary.]

Vasil'eva E.D. 2007. Ryby Černogo morâ. Opredelitel' morskih, solonovatovodnyh, êvrigalinnyh i prohodnyh vidov s cvetnymi illûstraciâmi, sobrannymi S.V. Bogorodskim [Fishes of the Black Sea. Key to marine, brackish-water, euryhaline, and anadromous species with colour illustrations collected by S.V. Bogorodsky.] Izdatel'stvo VNIRO/VNIR) Publishing, Moskva/Moscow, Russia. [In Russian with English summary.]

Vasil'eva E.D., Vasil'ev V.P., Boltachev A.R. 2005. Taxonomic relationships of gudgeons (Gobio, Gobioninae, Cyprinidae) of Crimea. Journal of Ichthyology 45 (9): 730-743.

Von Landwüst C. 2006. Expansion of Proterorhinus marmoratus (Teleostei, Gobiidae) into the River Moselle (Germany). Folia Zoologica 55 (1): 107-111.

Received: 26 November 2010 Accepted: 27 April 2011 Published electronically: 30 June 2011 